\title{
KEMAMPUAN SISWA MENEMUKAN DAN MEMAHAMI KONSEP LARUTAN ELEKTROLIT MENGGUNAKAN LEMBAR KERJA INDUKTIF
}

\author{
Irma Ayu Virtayanti ${ }^{1}$, Abudarin ${ }^{2}$ dan I Made Sadiana ${ }^{2}$ \\ ${ }^{1}$ Program Studi Pendidikan Kimia, Fakultas Keguruan dan IImu Pendidikan (FKIP), \\ Universitas Billfath, Lamongan, 62261, Indonesia \\ ${ }^{2}$ Program Studi Pendidikan Kimia, Fakultas Keguruan dan IImu Pendidikan (FKIP), \\ Universitas Palangka Raya, JI. Yos Sudarso, Palangka Raya, 73111, Indonesia \\ *E-mail: irma.virtayanti@gmail.com
}

\begin{abstract}
ABSTRAK
Penelitian ini bertujuan untuk mendeskripsikan kemampuan menemukan konsep dan kemampuan memahami konsep larutan elektrolit dan larutan nonelektrolit dalam pembelajaran menggunakan Lembar Kerja Siswa (LKS) dengan alur berpikir induktif siswa kelas X MIA-1 SMA Negeri 2 Palangka Raya tahun ajaran 2014/2015. Penelitian ini melibatkan 34 siswa kelas X. Data kemampuan menemukan konsep larutan elektrolit dan larutan nonelektrolit dikumpulkan dengan menggunakan instrumen LKS, sedangkan data pemahaman konsep larutan elektrolit dan larutan nonelektrolit dikumpulkan menggunakan soal tes pemahaman konsep bentuk uraian objektif. Validitas isi LKS dan soal tes pemahaman konsep ditentukan berdasarkan content validity coefficient menggunakan formula Aiken's V. Analisis data menggunakan statistik deskriptif untuk mendeskripsikan kemampuan siswa menemukan dan memahami konsep larutan elektrolit dan larutan nonelektrolit. Hasil penelitian menunjukkan bahwa kemampuan siswa menemukan konsep tentang larutan elektrolit dan larutan nonelektrolit dalam pembelajaran menggunakan LKS induktif rata-rata sebesar $91,17 \%$. Kemampuan siswa memahami konsep tentang larutan elektrolit dan larutan nonelektrolit dalam pembelajaran menggunakan LKS induktif rata-rata sebesar $80,59 \%$ yang tergolong dalam kategori baik. Siswa yang memiliki kemampuan menemukan konsep yang lebih baik cenderung menunjukkan pemahaman konsep yang lebih baik pula.
\end{abstract}

Kata kunci: penemuan konsep, pemahaman konsep, elektrolit, larutan nonelektrolit, lembar kerja induktif.

\begin{abstract}
This research aims to describe the ability to find the concept and the ability to understand the concept of electrolyte and nonelectrolyte solution in learning using the student worksheet with inductive thinking flow of X MIA- 1 students, SMA Negeri 2 Palangka Raya, school year 2014/2015. This research involves 34 students of $X$ grade. The ability to find the concept of electrolyte and nonelectrolyte solution data was collected by using the student worksheet instruments, while the ability to understand the concept of electrolyte and nonelectrolyte solution data was collected using objective test questions. The validity of the worksheet and test questions was determined based on content validity coeicient using Aiken's $V$ formula. The data was analysed using descriptive statistics to describe the students' ability to find and understand the concept of electrolyte and nonelectrolyte solution. The results showed that students' ability to find the concept of the electrolyte and nonelectrolyte solution in learning using inductive worksheet reached an average of $91.17 \%$. Students' ability to understand the concept of electrolyte and nonelectrolyte solution in learning using inductive worksheet reached an average of $80.59 \%$ that belongs in the good category. Students who have the ability to find the concept better tend to demonstrate better understanding of the concept.
\end{abstract}

Keywords: concept discovery, concept understanding, electrolyte, nonelectrolyte, inductive worksheets.

DOI: https://doi.org/10.15575/jtk.v3i2.2707 


\section{A. Virtayanti, Abudarin \& I. M. Sadiana}

\section{Pendahuluan}

Pesatnya perkembangan ilmu pengetahuan dan teknologi (IPTEK) menjadi pusat perhatian belakangan ini. Dasar pemicu perkembangan IPTEK ini tentu tidak lepas dari perkembangan sains. Hal ini menjadi pusat perhatian bagi para pendidik untuk meningkatkan sumber daya manusia di Indonesia dengan salah satu cara yaitu meningkatkan mutu pendidikan pada bidang sains. Kimia merupakan cabang sains yang menjadi salah satu mata pelajaran yang terdapat di sekolah. relevan dengan pendapat Medina (2015) yang menyatakan bahwa kimia memegang peranan penting dan memberikan kotribusi yang cukup besar bagi kehidupan manusia, maka mata pelajaran kimia dipelajari pada jenjang pendidikan Sekolah Menengah Pertama sampai ke Perguruan Tinggi.

Proses pembelajaran di sekolah merupakan suatu interaksi yang terstruktur dengan adanya tujuan pencapaian yang telah ditargetkan dan siswa mengalami perubahan setelah mengalami proses tersebut. Konsep dalam pembelajaran kimia sangat ditekankan. Konsep kimia terbentuk dalam diri siswa secara berangsur-angsur melalui pengalaman dan interaksi mereka dengan alam sekitarnya. Hal ini relevan dengan pendapat Herawati dkk. (2013), di mana melalui penyelesaian masalah dalam kehidupan yang nyata dengan menerapkan pengetahuan kimia, siswa diharapkan dapat membangun pengertian dan pemahaman konsep kimia lebih bermakna karena mereka membentuk sendiri struktur pengetahuan konsep kimia melalui bimbingan guru.

Pembelajaran merupakan suatu proses belajar guna mengembangkan kreativitas berpikir siswa. Hal ini relevan dengan pendapat Daryanti dkk. (2015) yang menyatakan bahwa pembelajaran dalam perspektif teori konstruktivistik adalah proses di mana siswa aktif secara mental mengonstruksi pengetahuan baru yang dilandasi oleh struktur kognitif siswa berdasarkan pengalaman. Pendekatan konstruktivistik
Kemampuan Siswa Menemukan dan Memahami Konsep Larutan Elektrolit Menggunakan Lembar Kerja Induktif merupakan pembelajaran yang menekankan pada peran aktif siswa dalam membangun pemahaman dan memberi makna terhadap informasi dan peristiwa yang dialami. Pendekatan konstruktivistik relevan dengan metode yang dikembangkan oleh Jerome Bruner yaitu pembelajaran penemuan (discovery learning). Menurut Burner, dalam proses pembelajaran, siswa hendaknya secara aktif menggunakan konsep-konsep atau prinsip-prinsip yang telah mereka kuasai dan melakukan penyelidikan atau eksperimen untuk menemukan konsep-konsep dan prinsip-prinsip yang baru (Trianto, 2010).

Hal tersebut sejalan dengan pendapat Poespoprodjo dan Gilarso (2009) bahwa berdasarkan karakteristik substansi yang dipelajari, proses mengonstruksi pengetahuan baru dalam belajar penemuan dapat mengikuti kerangka berpikir induktif maupun deduktif. Penalaran induktif lebih digemari dalam kerja ilmiah. Penalaran induktif adalah proses pemikiran di dalam akal kita dari pengetahuan tentang kejadian/peristiwa atau hal-hal yang konkret dan khusus untuk menyimpulkan pengetahuan yang lebih umum.

Selaras dengan pendapat tersebut, rendahnya penguasaan konsep siswa merupakan salah satu kendala dalam proses belajar mengajar kimia dan dapat berakibat pada rendahnya hasil belajar siswa. Teori kimia pada umumnya bersifat abstrak, berjenjang dan terstruktur. $\mathrm{Hal}$ ini juga menjadi penyebab siswa cenderung merasa kesulitan dalam memahami pelajaran kimia. Siswa juga tidak mampu mengartikan sifat kimia yang bersifat abstrak menjadi ilmiah. Ketidakmampuan tersebut membuat siswa dapat salah mengartikan konsep kimia secara benar.

Konsep merupakan suatu pemikiran yang mendasar tentang suatu objek berdasarkan ciri-ciri tertentu. Medina (2015) menyatakan bahwa setiap konsep memiliki elemen-elemen seperti nama, contoh dan ciri-ciri baik yang esensial maupun yang nonesensial. Namun pada kenyataannya tidak semua konsep sama 
I. A. Virtayanti, Abudarin \& I. M. Sadiana

dengan konsep para ilmuan. Relevan dengan pendapat Medina (2015) bahwa apabila konsepsi menyimpang atau bahkan bertentangan dengan konsepsi para kimiawan maka dikatakan siswa telah mengalami "kesalahan konsep kimia" atau mengalami miskonsepsi. Berdasarkan hasil observasi di SMA Negeri 2 Palangka Raya, guru masih menggunakan metode ceramah dan diiringi latihan-latihan soal. Proses pembelajaran guru lebih dominan, sehingga aktivitas siswa kurang dikarenakan siswa hanya menerima apa yang disampaikan oleh guru. Hal ini relevan dengan pendapat Anggareni dkk. (2013) bahwa proses pembelajaran yang dilaksanakan saat ini masih menggunakan paradigma lama yaitu pembelajaran yang berpusat pada guru.

Wawancara diadakan pada 13 Oktober 2014 dengan salah satu guru mata pelajaran kimia. Masalah yang ditemukan adalah bahwa siswa mengalami kesulitan ketika mempelajari konsep larutan elektrolit dan nonelektrolit. Hal ini dikarenakan kurangnya pemahaman siswa terhadap konsep pengetahuan tentang larutan elektrolit dan larutan nonelektrolit. Sehingga miskonsepsi pada siswa masih perlu ditinjau kembali untuk mengetahui seberapa besar pengertian yang tidak akurat tentang konsep yang masih dialami oleh siswa setelah pembelajaran dan untuk mengetahui efektivitas pembelajaran yang dialami siswa dalam mengatasi miskonsepsi. Hal ini jika dibiarkan akan berdampak kepada materi lanjutan dan akan mengalami miskonsepsi yang semakin kompleks (Medina, 2015).

Strategi dalam aktivitas belajar mengajar merupakan poin penting yang harus diperhatikan oleh guru. Salah satu strategi yang efektif untuk mengembangkan kreativitas siswa adalah strategi induktif. Hal ini relevan dengan pendapat Huda (2014) bahwa strategi induktif dalam pembelajaran merupakan strategi yang direncanakan untuk membantu siswa mengembangkan kemampuan berpikir tingkat tinggi dan kreativitas melalui observasi, membandingkan, menemukan pola, dan menggeneralisasikan.
Kemampuan Siswa Menemukan dan Memahami Konsep Larutan Elektrolit Menggunakan Lembar Kerja Induktif

Penggunaan strategi induktif adalah pilihan yang tepat dalam mempelajari kimia, karena siswa dilatih untuk menalar atau berpikir hingga mampu menemukan pengetahuannya sendiri (Abudarin, 2017). Sistem pembelajaran yang memberi kesempatan bagi siswa untuk aktif melakukan kegiatan belajar mengajar akan menyebabkan mereka terdorong untuk mempelajari materi khususnya kimia, sehingga apa yang diperoleh siswa lebih bermakna (Pinta, 2016). Oleh karena itu, siswa perlu diberikan panduan yang memuat tuntunan, bimbingan, atau arahan berpikir yang dikemas dalam bentuk lembar kerja siswa yang biasa disingkat LKS.

LKS merupakan lembaran-lembaran berisi tugas yang harus dikerjakan siswa. Relevan dengan hasil penelitian Abelta dkk. (2017), terdapat pengaruh signifikan terhadap hasil belajar siswa melalui pemahaman konsep siswa pada pembelajaran menggunakan LKS. Berdasarkan fenomena di atas, maka penelitian ini mengkaji kemampuan menemukan dan memahami konsep larutan elektrolit dan larutan nonelektrolit dalam pembelajaran menggunakan LKS dengan penalaran induktif.

\section{METODE PENELITIAN}

Penelitian ini menggunakan metode deskriptif yang mendeskripsikan kemampuan menemukan konsep dan kemampuan memahami konsep larutan elektrolit dan larutan nonelektrolit dalam pembelajaran menggunakan LKS dengan alur berpikir induktif. Populasi penelitian ini adalah seluruh siswa Kelas X Matematika dan IImu Alam (MIA) SMA Negeri 2 Palangka Raya Tahun Ajaran 2014/2015 terdiri dari enam kelas. Berdasarkan informasi yang diperoleh dari guru bidang studi kimia dua kelas yaitu kelas $X$ MIA-1 dan MIA-4 memiliki kemampuan yang homogen. Dalam penelitian ini kelas $X$ MIA-1 dipilih sebagai subjek penelitian, sedangkan $X \quad$ MIA-4 dipilih untuk kelas simulasi pembelajaran dan uji coba instrumen penelitian. 
I. A. Virtayanti, Abudarin \& I. M. Sadiana

Instrumen yang digunakan meliputi LKS induktif dan soal tes pemahaman konsep yang dikembangkan dengan mengacu pada indikator pembelajaran untuk materi larutan elektrolit dan larutan nonelektrolit. Sebelum digunakan di kelas LKS divalidasi terlebih dahulu oleh tiga orang ahli, yaitu dua dosen kimia Universitas Palangka Raya dan satu guru kimia sebagai pengguna. Hasil penilaian ini digunakan sebagai dasar untuk menentukan validitas isi menggunakan formula Aiken's $\mathrm{V}$ (Virtayanti dkk., 2017). Formula digunakan untuk menghitung koefisien validitas isi dengan persamaan sebagai berikut:

Keterangan:

$$
V=\Sigma s /[n(c-1)]
$$

$\mathrm{s}=\mathrm{r}-\mathrm{lo}$

lo $=$ angka penilaian validitas yang terendah

$\mathrm{c}=$ angka penilaian validitas yang terting $\mathrm{i}$

$r=$ angka yang diberikan oleh penilai.

Koefisien validitas isi LKS induktif diperoleh sebesar 0,86 dengan kategori sangat baik.

Teknik pengumpulan data ada dua tahap yaitu, pengumpulan data pemahaman konsep dan pengumpulan data penemuan konsep. Pertama, pemahaman siswa terhadap konsep larutan elektrolit dan nonelektrolit diukur menggunakan tes pemahaman konsep. Soal tes berbentuk uraian objektif terdiri dari lima butir soal, yang telah divalidasi. Hasil validasi soal didapatkan bahwa soal dapat digunakan untuk mengukur pemahaman konsep larutan elektrolit dan nonelektrolit dengan koefisien validitas isi (Aiken's V) sebesar satu. Soal tes juga diuji coba sacara empiris untuk mengukur daya beda, tingkat kesukaran dan reabilitas. Hasil uji coba empiris menyatakan bahwa soal memiliki daya pembeda yang cukup, tingkat kesukaran sedang, dan reabilitas sebesar 0,89, artinya soal dikategorikan baik.

Kedua, penemuan konsep oleh siswa dapat diukur dengan cara memberikan LKS induktif dan dikerjakan secara berkelompok. Adapun tahapannya sebagai berikut; (1) masing-
Kemampuan Siswa Menemukan dan Memahami Konsep Larutan Elektrolit Menggunakan Lembar Kerja Induktif

masing siswa dibentuk dalam beberapa kelompok; (2) tiap anggota kelompok mengisi data hasil percobaan pada LKS yang disertai bimbingan guru; (3) tiap kelompok mempresentasikan hasil diskusinya di depan kelas; (4) siswa diarahkan untuk menyimpulkan sendiri konsep dari hasil pengisian LKS induktif.

Teknik analisis data pada penemuan konsep dapat diketahui dari LKS induktif yang dikerjakan siswa. Teknik analisis data yang digunakan untuk mendeskripsikan dan menganalisis kemampuan siswa dalam menemukan konsep larutan elektrolit dan larutan nonelektrolit berdasarkan beberapa kegiatan belajar pada LKS induktif yang dikerjakannya adalah menggunakan persamaan berikut:

$$
\begin{aligned}
& \text { Persen siswa menemukan konsep } \\
& =\frac{\text { Total siswa menemukan konsep }}{\text { total siswa }} \times 100 \%
\end{aligned}
$$

Analisis data pada pemahaman konsep menggunakan data nilai hasil pretest dan posttest. Data pemahaman konsep yang berupa data nilai pretest dan posttest serta hasil wawancara dianalisis dengan langkahlangkah sebagai berikut: (1) data yang diperoleh dari lembar jawaban siswa dianalisis dengan cara memberi skor berdasarkan kriteria pemberian skor setiap butir soal; (2) mengkonversi total skor pretest dan posttest dari lembar jawaban masing-masing siswa ke bentuk persentase; (3) mendeskripsikan data nilai pretest dan posttest siswa berdasarkan lembar jawaban pretest dan posttest yang telah diolah dan dikonversi dalam bentuk persentase; (4) menganalisis tingkat pemahaman siswa dalam memahami konsep larutan elektrolit dan larutan nonelektrolit dari hasil pretest dan posttest berdasarkan persentase pemahaman; (5) menghitung jumlah siswa yang mengalami pergeseran skor maksimum masing-masing indikator (butir soal); (6) menganalisis pemahaman konsepkonsep larutan elektrolit dan larutan nonelektrolit yang dapat dihubungkan dengan 
hasil siswa mengerjakan LKS induktif, dan aktivitas belajar kelompok siswa maupun dari hasil wawancara dengan perwakilan siswa yang bersangkutan.

\section{HASIL DAN PEMBAHASAN}

\subsection{Kemampuan Siswa Menemukan Konsep Larutan Elektrolit dan Larutan Nonelektrolit}

Hasil analisis data menunjukkan bahwa kemampuan subjek penelitian dalam menemukan konsep-konsep larutan elektrolit dan nonelektrolit tergolong sangat baik. Relevan dengan hasil penelitian Abelta dkk. (2017) bahwa dalam penggunaan LKS berbasis inkuiri terbimbing untuk melihat kemampuan pemahaman konsep siswa, guru dapat mengarahkan siswa untuk mendapatkan konsep yang diperoleh dari fakta, peristiwa, pengalaman melalui generalisasi dan berpikir abstrak melalui berbagai proses kegiatan mental yang melatih kemampuan untuk menafsirkan keadaan yang ada di sekitarnya. Hasil penelitian ini dapat dilihat pada Tabel 1.

Data pada Tabel 1 tersebut menunjukkan jumlah siswa dalam menemukan konsepkonsep tentang larutan elektrolit dan larutan nonelektrolit. Konsep pertama merupakan konsep tentang definisi larutan elektrolit dan larutan nonelektrolit. Konsep kedua merupakan konsep tentang peristiwa penguraian atau ionisasi senyawa yang tergolong larutan elektrolit.

Jumlah siswa yang dapat menemukan konsep pada konsep pertama menunjukkan bahwa jumlah siswa yang dapat menemukan definisi larutan elektrolit dan larutan nonelektrolit pada semua kelompok adalah 100\%. Hal tersebut menandakan semua siswa (34 orang) dapat menemukan definisi larutan elektrolit dan larutan nonelektrolit. Hal ini menunjukkan bahwa seluruh siswa sudah dapat menjelaskan definisi larutan elektrolit dan larutan nonelektrolit dengan benar.
Tabel 1. Data Jumlah Siswa dalam Menemukan Konsep-Konsep tentang Larutan Elektrolit dan Larutan Nonelektrolit

\begin{tabular}{|c|c|c|c|c|c|}
\hline \multirow{3}{*}{$\begin{array}{l}\text { Kelom- } \\
\text { pok }\end{array}$} & \multirow{3}{*}{$\begin{array}{l}\text { Jumlah } \\
\text { Anggota }\end{array}$} & \multicolumn{4}{|c|}{$\begin{array}{c}\text { Jumlah Siswa yang dapat } \\
\text { Menemukan Konsep }\end{array}$} \\
\hline & & \multicolumn{2}{|c|}{ Konsep 1} & \multicolumn{2}{|c|}{ Konsep 2} \\
\hline & & Orang & $\%$ & Orang & $\%$ \\
\hline $\mathrm{I}$ & 5 & 5 & 100 & 3 & 60 \\
\hline II & 5 & 5 & 100 & 3 & 60 \\
\hline III & 5 & 5 & 100 & 5 & 100 \\
\hline IV & 5 & 5 & 100 & 5 & 100 \\
\hline $\mathrm{V}$ & 5 & 5 & 100 & 5 & 100 \\
\hline $\mathrm{VI}$ & 5 & 5 & 100 & 4 & 80 \\
\hline VII & 4 & 4 & 100 & 3 & 75 \\
\hline \multicolumn{2}{|c|}{ Total } & \multicolumn{2}{|c|}{$\begin{array}{c}34 \text { orang } \\
(100 \%)\end{array}$} & \multicolumn{2}{|c|}{$\begin{array}{l}28 \text { orang } \\
(82,35 \%)\end{array}$} \\
\hline
\end{tabular}

Adapun jumlah siswa yang dapat menemukan konsep pada konsep kedua menunjukkan bahwa jumlah siswa yang dapat menemukan peristiwa penguraian atau ionisasi senyawa yang tergolong larutan elektrolit pada tiap kelompok adalah kelompok I dan II sebanyak $60 \%$ (tiga orang), kelompok III, IV, dan V sebanyak $100 \%$ (lima orang), kelompok IV sebanyak $80 \%$ (empat orang), dan kelompok VI sebanyak 75\% (tiga orang). Secara keseluruhan, sebanyak $82,35 \%$ (28 orang) dapat menemukan peristiwa penguraian atau ionisasi senyawa yang tergolong larutan elektrolit. Hal ini menunjukkan bahwa sebagian besar siswa sudah dapat menjelaskan peristiwa penguraian atau ionisasi senyawa yang tergolong larutan elektrolit. Sedangkan sebagian kecilnya tidak dapat menjelaskan peristiwa penguraian atau ionisasi senyawa yang tergolong larutan elektrolit dengan benar. Dari data tersebut menunjukkan siswa lebih dominan mampu menemukan konsep kedua yang terealisasi dengan kemampuan mereka mengisi LKS dengan benar.

\subsubsection{Kemampuan Siswa Menemukan Definisi Larutan Elektrolit dan Larutan Nonelektrolit}

Definisi larutan elektrolit dan larutan nonelektrolit dapat ditemukan dengan cara menganalisis data hasil percobaan di kegiatan belajar pertama pada LKS induktif. Pada 
kegiatan belajar pertama siswa melakukan percobaan yang bertujuan agar siswa dapat memperoleh definisi yang tepat tentang larutan elektrolit dan nonelektrolit berdasarkan data daya hantar hasil percobaan. Dari data percobaan tersebut, siswa diminta untuk menyimpulkan definisi larutan elektrolit dan larutan nonelektrolit berdasarkan daya hantar listriknya. Sebanyak 100\% (34 orang) dapat menemukan definisi larutan elektrolit dan larutan nonelektrolit dengan benar.

Jika larutan garam $(\mathrm{NaCl})$, larutan asam klorida $(\mathrm{HCl})$ yang Anda uji merupakan larutan elektrolit, maka dari data diatas yang dimaksud dengan larutan elektrolit

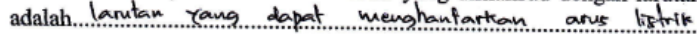

Sebaliknya, larutan gula dan larutan urea yang Anda uji merupakan larutan nonelektrolit, maka dari data diatas yang dimaksud dengan larutan nonelektrolit

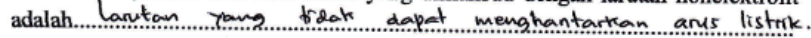

Berdasarkan hasil percobaan larutan $\mathrm{CH}_{3} \mathrm{COOH}$ tidak dapat menyalakan lampu, tetapi timbul gelembung gas. Larutan $\mathrm{CH}_{3} \mathrm{COOH}$ tersebut dapat menghantarkan arus listrik tetapi daya hantarnya lemah sehingga lampu tidak menyala. Senyawa seperti ini disebut elektrolit lemah.

\section{Gambar 1. Contoh Hasil Kerja Siswa yang dapat Menemukan Konsep Pertama pada Kegiatan Belajar Pertama}

Gambar 1 merupakan contoh hasil kerja siswa yang dapat menemukan definisi larutan elektrolit dan larutan nonelektrolit dengan benar. Terlihat siswa dapat menyimpulkan pengertian larutan elektrolit dan larutan nonelektrolit pada kolom kesimpulan dengan benar.

\subsubsection{Kemampuan Siswa Menemukan Peristiwa Penguraian atau Ionisasi Senyawa yang Tergolong Larutan Elektrolit}

Peristiwa penguraian atau ionisasi senyawa yang tergolong larutan elektrolit dapat ditemukan dengan cara menelaah wacana yang diberikan di kegiatan belajar kedua pada LKS induktif. Siswa diminta untuk menyimpulkan peristiwa penguraian atau ionisasi senyawa yang tergolong larutan elektrolit. Sebanyak $82,35 \%$ (28 orang) dapat menemukan peristiwa penguraian atau
Kemampuan Siswa Menemukan dan Memahami Konsep Larutan Elektrolit Menggunakan Lembar Kerja Induktif

ionisasi senyawa yang tergolong larutan elektrolit dengan benar.

Gambar 2 menyajikan contoh hasil kerja siswa yang dapat menemukan konsep peristiwa penguraian atau ionisasi senyawa yang tergolong larutan elektrolit dengan benar. Terlihat siswa telah mampu menjelaskan proses ionisasi pada senyawa yang tergolong elektrolit, sehingga siswa dapat menyimpulkan peristiwa penguraian atau ionisasi senyawa yang tergolong larutan elektrolit pada kolom kesimpulan dengan benar.

Larutan $\mathrm{NaCl}$, larutan $\mathrm{HCl}$, dan larutan $\mathrm{CH}_{3} \mathrm{COOH}$ merupakan larutan elektrolit yang dapat menghantarkan arus listrik. Suatu larutan dapat menghantarkan arus listrik jika di dalamnya terdapat ion-ion. Dengan demikian dapat dinyatakan bahwa dalam larutan $\mathrm{NaCl}$, larutan $\mathrm{HCl}$, dan larutan $\mathrm{CH}_{3} \mathrm{COOH}$ terdapat ....................... Hal tersebut menunjukkan bahwa senyawa $\mathrm{NaCl}$ (ionik), senyawa $\mathrm{HCl}$ (kovalen polar), dan senyawa $\mathrm{CH}_{3} \mathrm{COOH}$ (kovalen polar)

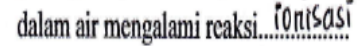

Jadi dapat disimpulkan bahwa senyawa ionik dan senyawa kovalen polar didalam air (pelarut polar) dapat mengalami reaksi innissusi yang menghasilkan ion

Gambar 2. Contoh Hasil Kerja Siswa yang dapat Menemukan Konsep Kedua pada Kegiatan Belajar Kedua

\subsection{Kemampuan Siswa Memahami Konsep Larutan Elektrolit dan Larutan Nonelektrolit}

Kemampuan siswa memahami konsep-konsep tentang larutan elektrolit dan nonelektrolit diukur menggunakan tes tertulis bentuk uraian objektif yang dikembangkan dengan mengacu pada indikator capaian belajar. Nilai pemahaman siswa pada setiap konsep disajikan pada Tabel 2.

Hasil pengukuran pemahaman konsep menunjukkan bahwa rata-rata siswa mampu memahami $80,59 \%$ pengetahun tentang larutan elektrolit dan larutan nonelektrolit. 
Terlihat pada konsep definisi atau pengertian siswa memahami konsep dengan nilai 94,12. Pada bagian perbandingan siswa memahami konsep dengan nilai sempurna yaitu 100. Pada pengklasifikasian siswa memperoleh nilai 94,12 . Bagian konsep penguraian siswa memperoleh nilai hampir sempurna yaitu 97,05. Konsep perbedaan kedua larutan siswa mendapat nilai 17,65 .

Tabel 2. Pemahaman Siswa Kelas X MIA-1 SMAN 2 Palangka Raya Tentang Larutan Elektrolit dan Larutan Nonelektrolit

\begin{tabular}{|l|c|}
\hline \multicolumn{1}{|c|}{ Konsep } & Pemahaman konsep \\
\hline $\begin{array}{l}\text { Pengertian Larutan } \\
\text { Elektrolit dan } \\
\text { Nonelektrolit }\end{array}$ & 94,12 \\
\hline $\begin{array}{l}\text { Perbedaan Larutan } \\
\text { Elektrolit dan } \\
\text { Nonelektrolit }\end{array}$ & 100 \\
\hline $\begin{array}{l}\text { Klasifikasi Larutan ke } \\
\text { dalam Larutan Elektrolit } \\
\text { dan Nonelektrolit }\end{array}$ & 94,12 \\
\hline $\begin{array}{l}\text { Peristiwa Penguraian atau } \\
\text { lonisasi Senyawa yang } \\
\text { Tergolong Larutan } \\
\text { Elektrolit }\end{array}$ & 97,06 \\
\hline $\begin{array}{l}\text { Perbedaan Elektrolit Kuat } \\
\text { dan Elektrolit Lemah, } \\
\text { Hubungannya dengan } \\
\text { lonisasi }\end{array}$ & 17,65 \\
\hline \multicolumn{1}{|c|}{ Rata -rata } & 80,59 (baik) \\
\hline
\end{tabular}

Hasil penelitian ini relevan dengan penelitian yang telah dilakukan Dewi dkk. (2016) dalam penelitiannya tentang penguasaan konsep larutan elektrolit dan nonelektrolit dengan siklus belajar hipotesis deduktif, di mana konsep yang paling dikuasai siswa adalah konsep dari indikator mengklasifikasikan larutan dalam kehidupan sehari-hari ke dalam kelompok larutan elektrolit dan nonelektrolit yang menunjukkan kriteria sangat baik sedangkan konsep yang masih kurang dikuasai siswa adalah konsep dari indikator menjelaskan keadaan partikel-partikel zat terlarut dalam larutan elektrolit kuat, elektrolit lemah dan nonelektrolit yang menunjukkan kriteria cukup.
Kemampuan Siswa Menemukan dan Memahami Konsep Larutan Elektrolit Menggunakan Lembar Kerja Induktif

\subsubsection{Kemampuan Siswa Memahami Pengertian Larutan Elektrolit dan Larutan Nonelektrolit}

Konsep pengertian larutan elektrolit dan nonelektrolit sesuai dengan indikator pertama yang ingin dicapai dalam pembelajaran. Pemahaman konsep pengertian larutan elektrolit dan nonelektrolit dapat dilihat dari perbandingan hasil jawaban pretest dan posttest siswa pada butir soal pertama. Skor yang diberikan pada butir soal pertama berada pada rentang 0-2. Skor dua berarti siswa mampu mendeskripsikan pengertian larutan elektrolit dan larutan nonelektrolit. Perubahan skor siswa saat pretest dan posttest menunjukkan adanya pergeseran skor yang diperoleh siswa dari pretest ke posttest.

Berdasarkan data, jumlah siswa yang mendapatkan skor maksimal adalah pada pergeseran skor nol ke skor dua sebanyak 55,88\% (19 siswa) dan siswa yang tidak mengalami pergeseran skor dua sebanyak $38,24 \%$ (13 siswa). Oleh karena itu, jumlah siswa yang dapat mendeskripsikan pengertian larutan elektrolit dan nonelektrolit adalah $94,12 \%$ (32 siswa).

\subsubsection{Kemampuan Siswa Memahami Perbedaan Larutan Elektrolit dan Larutan Nonelektrolit}

Konsep perbedaan larutan elektrolit dan nonelektrolit sesuai dengan indikator kedua yang ingin dicapai dalam pembelajaran. Pemahaman konsep perbedaan larutan elektrolit dan nonelektrolit dapat dilihat dari perbandingan hasil jawaban pretest dan posttest siswa pada butir soal kedua. Skor yang diberikan pada butir soal kedua berada pada rentang 0-1. Skor satu berarti siswa dapat membedakan larutan elektrolit dan larutan nonelektrolit berdasarkan daya hantar listrik. Perubahan skor siswa saat pretest dan posttest ini menunjukkan adanya pergeseran skor yang diperoleh siswa dari pretest ke posttest.

Berdasarkan data, jumlah siswa yang mendapatkan skor maksimal adalah pada 
I. A. Virtayanti, Abudarin \& I. M. Sadiana

pergeseran skor nol ke skor satu sebanyak $67,65 \%$ (23 siswa) dan siswa yang tidak mengalami pergeseran skor satu sebanyak 32,35\% (11 siswa), jadi jumlah siswa dapat membedakan larutan elektrolit dan nonelektrolit adalah 100\% (34 siswa).

\subsubsection{Kemampuan Siswa Memahami Klasifikasi Larutan ke dalam Larutan Elektrolit dan Nonelektrolit}

Konsep klasifikasi larutan ke dalam larutan elektrolit dan larutan nonelektrolit sesuai dengan indikator ketiga yang ingin dicapai dalam pembelajaran. Pemahaman konsep siswa pada klasifikasi larutan ke dalam larutan elektrolit dan larutan nonelektrolit dapat dilihat dari perbandingan hasil jawaban pretest dan posttest siswa pada butir soal ketiga. Butir soal ketiga terdiri dari dua bagian pertanyaan mengenai: 1) larutan yang termasuk elektrolit; 2) larutan yang termasuk nonelektrolit. Skor maksimum untuk butir soal ketiga adalah empat jika siswa mampu mengklasifikasikan larutan ke dalam larutan elektrolit atau Iarutan nonelektrolit. Oleh sebab itu, skor pada indikator ini dibagi menjadi dua, yaitu klasifikasi larutan ke dalam larutan elektrolit dan klasifikasi larutan ke dalam larutan nonelektrolit. Dengan skor maksimum pada masing-masing sub indikator adalah dua. Berdasarkan data jumlah siswa dapat mengklasifikasikan larutan ke dalam larutan elektrolit dan larutan nonelektrolit adalah 94,12\% (32 siswa).

\subsubsection{Kemampuan Siswa Memahami Peristiwa Penguraian atau Ionisasi Senyawa yang Tergolong Larutan Elektrolit}

Konsep peristiwa penguraian atau ionisasi senyawa yang tergolong larutan elektrolit sesuai dengan indikator keempat yang ingin dicapai dalam pembelajaran. Pemahaman konsep peristiwa penguraian atau ionisasi senyawa yang tergolong larutan elektrolit pada siswa dapat dilihat dari perbandingan hasil jawaban pretest dan posttest pada butir
Kemampuan Siswa Menemukan dan Memahami Konsep Larutan Elektrolit Menggunakan Lembar Kerja Induktif

soal keempat. Skor yang diberikan pada butir soal keempat berada pada rentang 0-3.

Berdasarkan data, jumlah siswa yang mendapatkan skor maksimal adalah pada pergeseran skor nol ke skor tiga sebanyak 97,06\% (33 siswa). Jadi, jumlah siswa yang dapat menjelaskan peristiwa penguraian atau ionisasi senyawa yang tergolong larutan elektrolit adalah 97,06\% (33 siswa).

\subsubsection{Kemampuan Siswa Memahami Perbedaan Elektrolit Kuat dan Elektrolit Lemah Hubungannya dengan Ionisasi}

Konsep perbedaan elektrolit kuat dan elektrolit lemah hubungannya dengan ionisasi sesuai dengan indikator kelima yang ingin dicapai dalam pembelajaran. Pemahaman konsep perbedaan elektrolit kuat dan elektrolit lemah hubungannya dengan ionisasi dapat dilihat dari perbandingan hasil jawaban pretest dan posttest siswa pada butir soal kelima. Skor yang diberikan pada butir soal kelima berada pada rentang 0-2.

Berdasarkan data, jumlah siswa yang mendapatkan skor maksimal adalah pada pergeseran skor nol ke skor dua sebanyak $17,65 \%$ (enam siswa). Jadi, jumlah siswa dapat menjelaskan perbedaan elektrolit kuat dan elektrolit lemah serta hubungannya dengan ionisasi adalah 17,65\% (enam siswa). Hal ini memperlihatkan bahwa kemampuan siswa dalam memahami perbedaan elektrolit kuat dan elektrolit lemah masih rendah.

\subsection{Hubungan Kemampuan Menemukan Konsep terhadap Pemahaman Konsep}

Pemahaman konsep larutan elektrolit dan nonelekrolit dalam penelitian ini diperoleh siswa melalui proses belajar menggunakan alur penalaran induktif yang dipandu menggunakan LKS. Pemahaman konsep siswa dalam pembelajaran dengan alur penalaran induktif tergantung pada kemampuan siswa mengonstruksi konsep-konsep yang harus mereka pahami. Relevan dengan hasil 
penelitian Kurniawati dkk. (2016) bahwa LKS memberi bantuan berupa rangkaian susunan pembelajaran yang akan mereka pelajari dengan menekankan pada aspek-aspek tertentu sehingga dapat meningkatkan aktivitas yang berupa keterampilan dalam proses pembelajaran.

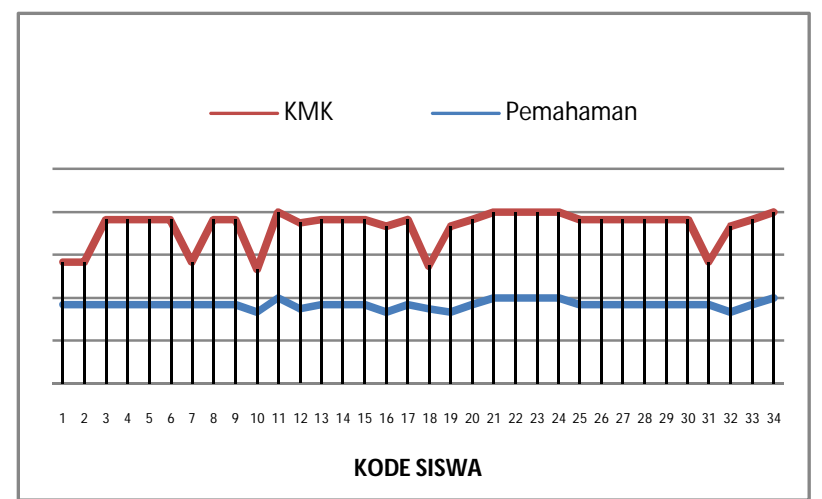

\section{Gambar 3. Hubungan KMK terhadap Pemahaman}

Gambar 3. menyandingkan kurva kemampuan menemukan konsep dan pemahaman konsep siswa tentang larutan elektrolit dan larutan nonelektrolit. Kurva tersebut menunjukkan bahwa siswa yang memiliki Kemampuan menemukan konsep yang lebih baik cenderung menunjukkan pemahaman konsep yang lebih baik pula.

\section{KESIMPULAN}

Berdasarkan hasil penelitian yang telah ditemukan maka dapat disimpulkan bahwa kemampuan siswa kelas X MIA-1 SMA Negeri 2 Palangka Raya tahun ajaran 2014/2015 dalam menemukan konsep tentang larutan elektrolit dan larutan nonelektrolit pada pembelajaran menggunakan LKS induktif ratarata sebesar $91,17 \%$. Kemampuan siswa kelas $X$ MIA-1 SMA Negeri 2 Palangka Raya tahun ajaran 2014/2015 memahami konsep tentang larutan elektrolit dan larutan nonelektrolit dalam pembelajaran menggunakan LKS induktif rata-rata sebesar $80,59 \%$ yang tergolong dalam kategori baik. Siswa yang memiliki kemampuan menemukan konsep yang lebih baik cenderung menunjukkan pemahaman konsep yang lebih baik pula.
Kemampuan Siswa Menemukan dan Memahami Konsep Larutan Elektrolit Menggunakan Lembar Kerja Induktif

Siswa yang berhasil mengisi LKS dengan benar tentang larutan elektrolit dan larutan nonelektrolit disimpulkan telah mampu menemukan dan memahami konsep dengan baik. Berdasarkan hasil penelitian dapat disimpulkan bahwa kemampuan menemukan dan memahami konsep menggunakan LKS induktif dapat meningkatkan keterampilan dan hasil belajar siswa kelas X MIA-1 SMA Negeri 2 Palangka Raya tahun ajaran 2014/2015 pada materi larutan elektrolit dan larutan nonelektrolit.

\section{UCAPAN TERIMA KASIH}

Penelitian ini dapat diselesaikan dengan baik tidak terlepas dari bantuan beberapa pihak. Penulis mengucapkan terima kasih kepada Dra. Badah Sari, MM., selaku Kepala Sekolah SMAN 2 Palangka Raya yang telah memberi izin untuk mengadakan penelitian di sekolah ini. Peneliti juga mengucapkan terima kasih kepada guru mata pelajaran kimia kelas $X$ MIA-1 SMAN 2 Palangka Raya tahun ajaran 2014/2015 yang telah memberi dukungan dengan kesediaan diwawancara oleh peneliti dan mengizinkan peneliti untuk menggunakan kelas yang diampu. 


\section{A. Virtayanti, Abudarin \& I. M. Sadiana}

\section{DAFTAR PUSTAKA}

Abelta, G. A, Ertikanto, C. \& Wahyudi, I. (2017). Pengaruh Penggunaan LKS Berbasis Inkuiri Terbimbing terhadap Hasil Belajar Melalui Pemahaman Konsep. Jurnal Pembelajaran Fisika, 5(2), 93104.

Abudarin. (2017). Kemampuan Siswa Kelas XI SMA Negeri 4 Palangka Raya dalam Mengonstruksi dan Memahami Hidrolisis Garam Melalui Penalaran Induktif dengan Panduan LKS.Prosiding Seminar Nasional Kimia dan Pendidikan Kimia, FKIP, Universitas Sebelas Maret, 111-120, Surakarta: Universitas Sebelas Maret.

Anggareni, N. W., Ristiati, N. P. \& Widiyanti, N. L. P. M. (2013). Implementasi Strategi Pembelajaran Inkuiri Terhadap Kemampuan Berpikir Kritis dan Pemahaman Konsep IPA Siswa SMP.Jurnal Program Pascasarjana Universitas Pendidikan Ganesha, 3(1), $1-3$.

Daryanti, E.P., Rinato, Y. \& Dwiastuti, S. (2015). Peningkatan Kemampuan Penalaran Ilmiah Melalui Model Pembelajaran Inkuiri Terbimbing Pada Materi Sistem Pernapasan Manusia. Jurnal Pendidikan Matematika dan Sains, 163-168.

Dewi, R., Supriyanti, F. M. T. \& Dwiyanti, G. (2016). Analisis Penguasaan Konsep Larutan Elektrolit-Nonelektrolit Siswa Menggunakan Siklus Belajar Hipotesis Deduktif. Jurnal Kimia dan Pendidikan.1(2).98-109.

Herawati, R. F., Mulyani, S. \& Redjeki, T. (2013). Pembelajaran kimia berbasis multiple representasi ditinjau dari kemampuan awal terhadap prestasi belajar laju reaksi siswa SMA Negeri 1 Karanganyar tahun pelajaran 2011/2012. Jurnal Pendidikan Kimia (JPK), 2(2), 1-2.
Kemampuan Siswa Menemukan dan Memahami Konsep Larutan Elektrolit Menggunakan Lembar Kerja Induktif

Huda, M. (2014). Model-Model Pengajaran dan Pembelajaran. Yogyakarta: Pustaka Pelajar.

Kurniawati, D., Masykuri, M. \& Saputro, S. (2016). Penerapan Model Pembelajaran Inkuiri Terbimbing dilengkapi LKS untuk Meningkatkan Keterampilan Proses Sains dan Prestasi Belajar pada Materi Pokok Hukum Dasar Kimia Siswa Kelas X MIA 4 SMA Negeri 1 Karanganyar Tahun Pelajaran 2014/2015. Jurnal Pendidikan Kimia, $5(1), 90-92$.

Medina, P. (2015). Analisis Miskonsepsi Siswa Kelas X Pada Materi Larutan dan Non Elektrolit Serta Reaksi Oksidasi Dan Reduksi Dalam Pembelajaran Kimia Di SMAN Kota Padang.Jurnal Pendidikan dan Teknologi Informasi, 2(1), 1-9.

Pinta, Y. (2016). Pengaruh Permainan Kareki Terhadap Hasil Bealajar Siswa Pada Materi Ikatan Ion di SMA Islam Raudhatul Jannah Payakumbuh. Jurnal Tadris Kimiya, 1(2), 79-83.

Poespoprodjo \& Gilarso. (2009). Logika Ilmu Menalar, Dasar-dasar Berpikir Tertib, Logis, Kritis, Analitis, Dialektis. Bandung: Pustaka Grafika.

Trianto. (2010). Mendesain Model Pembelajaran Inovatif-Progresif (Konsep, Landasan, dan Implementasinya pada Kurikulum Tingkat Satuan Pendidikan (KTSP)). Jakarta: Kencana.

Virtayanti, I. A., Abudarin \& Wijayanti, E. (2017). Pengembangan Lembar Kerja Siswa Berorientasi Keterampilan Generik Sains Dalam Pembelajaran Kesetimbangan Kimia (Studi di SMAN 4 Palangka Raya).Prosiding Seminar Nasional Kimia dan Pendidikan Kimia, FKIP, Universitas Sebelas Maret, 92-99, Surakarta: Universitas Sebelas Maret. 